\title{
Mechanical Harvesting Has Little Effect on Water Status and Leaf Gas Exchange in Citrus Trees
}

\author{
Kuo-Tan Li ${ }^{1}$ and James P. Syvertsen \\ University of Florida, Institute of Food and Agricultural Sciences, Citrus Research and Education \\ Center, Lake Alfred, FL 33850
}

\begin{abstract}
AdDitional INDEX words. sweet orange, Citrus sinensis, trunk shaker, photosynthesis, chlorophyll fluorescence, water potential, drought stress

Aвstract. Mechanical harvesting of citrus trees can cause physical injuries, such as shedding of leaves, exposing roots, and scuffing bark. Although mechanical harvesting usually has not reduced yield, physiological consequences to the tree from these visible injuries have not been investigated. We hypothesized that physical injuries to tree canopies and root systems from a properly operated trunk shaker would not cause short-term physiological effects. Tree water status and leaf gas exchange of mature 'Hamlin' and 'Valencia' sweet orange [Citrus sinensis (L.) Osb.] trees that were harvested by a trunk shaker were compared to hand-harvested trees. A trunk shaker was operated with adequate duration to remove $>90 \%$ of mature fruit or with excessive shaking time under various environmental conditions and drought stress treatments throughout the harvest season. Mid-day stem $\left(\Psi_{\text {stem }}\right)$ and leaf $\left(\Psi_{\text {leaf }}\right)$ water potentials along with leaf gas exchange were measured before and after harvest. Trees harvested by the trunk shaker did not develop altered water status under most conditions. Trees harvested with excessive shaking time and/or with limited soil water supply developed low $\Psi_{\text {stem }}$ resembling $\Psi_{\text {stem }}$ of drought-stressed trees. However, water potential of all treatments recovered to values of the well-irrigated, hand-harvested trees after rainfall. In addition, mechanical harvesting did not reduce $\mathrm{CO}_{2}$ assimilation, transpiration, stomatal conductance, water use efficiency, or photosystem II efficiency as measured by chlorophyll fluorescence. Thus, despite visible injuries, a properly operated trunk shaker did not result in any measurable physiological stress.
\end{abstract}

Mechanical harvesting of fruit crops gained its first major thrust in the1930s (O'Brien et al., 1983), and the principles of machinery-operated harvesting as well as its economical value have been developed ever since. Numerous types of harvest machines have been designed and commercially applied in various fruit industries including citrus in Florida (Hedden et al., 1983; Whitney, 1995). The major benefit of mechanical harvesting relies on its efficiency and lower costs in comparison to harvesting by hand, thereby increasing grower profit. However, the adoption of mechanical harvesting in Florida's citrus industry has been unexpectedly slow. By $2003<3 \%$ of its 240,000 ha of processed orange groves were mechanically harvested (Brown, 2005).

Many factors contribute to the lack of widespread adoption of mechanical harvesting by the Florida citrus industry. Among these factors is the apparent violent shaking that trees experience during harvesting with trunk or canopy shakers. This is usually the grower's first impression of mechanical harvesting. Depending on the type of the harvest machines, the skill of the operators, the weather, the grove conditions, and the physiological status of the trees, a harvest machine can cause visible physical injuries to the trees. These include shedding of leaves, flowers, and young fruit, breaking branches, scuffing of bark, and exposing roots (Halderson, 1966). Nevertheless, long-term studies revealed that fruit yield of citrus trees was affected little by mechanical harvesting com-

Received for publication 25 Jan. 2005. Accepted for publication 21 Mar. 2005. We thank John Crum from FMC Corp. for use of the trunk shaker and data acquisition systems. Fernando Alferez, Baylis Carnes, Jill Dunlop, Igor Kostenyuk, Luis Pozo, Ana Redondo, Shila Singh, Zhencai Wu, and Rongcai Yuan assisted in harvest. Thanks to Jackie Burns and Richard Buker for critical reviews. Mention of a trademark does not imply endorsement of the product named, or criticism of similar products not named. This work was supported by UF/IFAS and partially funded by the Florida Dept. of Citrus. Florida Agricultural Experiment Stations Journal Series No. R-10706.

1To whom reprint requests should be addressed; e-mail ktli@ufl.edu. pared to trees that were hand harvested (Hedden et al., 1988). In cherry (Prunus cerasus L.) trees, however, mechanical harvesting hastened tree decline and cut their productive life in half (Burton et al., 1986). Although there is no evidence that visible injuries could seriously weaken citrus trees, tree health after mechanical harvesting remains a major concern to orange growers.

Previous studies have concentrated on finding the potential cause of mechanical injuries (Abdel-Fattah, et al., 2003; Gurusinghe and Shackel, 1995) as well as improving machinery design and harvest efficiency (Affeldtet al., 1989; Fridley, 1983; Peterson, 1998). It is apparent that currently available harvest machines have been greatly improved and tree injures caused by modern shaking machines are less severe than they once were. On the other hand, it also appears that unless a more sophisticated means of mechanical harvesting is employed, some visible tree injuries are unavoidable. This underscores the need to document the tree's physiological responses to injuries by mechanical harvesters.

Despite the fact that secondary infections after immediate injuries have been blamed for tree decline in mechanical harvested cherry, almond [Prunus dulcis (Mill.) Webb.] (De Vay et al., 1968), and peach [Prunus persica (L.) Batsch.] (Glenn, et al., 1995) trees, physiological reactions to physical injuries by harvest machines to these fruit trees or to citrus, have not been documented. In 2003, we initiated the first program dedicated to investigating the effects of mechanical harvesting on tree physiological activity in citrus trees. The objectives of this program were to 1) quantify the relationship between harvest machines and the potential of short and long-term physiologically important injuries, 2) examine the physiological effects of mechanical harvesting under different weather conditions and tree water status over the 6-month-long harvest season, and 3) develop safe operating conditions for mechanical harvesting to avoid tree injury in an effort to accelerate the adoption of mechanical harvesting in the Florida citrus industry. 
We measured tree water status and leaf gas exchange characteristics after harvesting by a trunk shaker, one of the most popular harvest machine types in Florida. We hypothesized that the severity of injuries caused by a normally operating trunk shaker would not induce significant physiological stresses in well-managed citrus trees. In addition, if a tree that was under environmental stresses or was actively growing, it likely would be more vulnerable to any physiological stress induced from mechanical harvesting with an improperly operated shaker.

\section{Materials and Methods}

Three grove sites of 'Hamlin' or 'Valencia' sweet orange $(C$. sinensis) trees on Carrizo citrange $[$ C . sinensis $\mathrm{x}$ Poncirus trifoliate (L.) Raf.] or Swingle citrumelo (C. paradise Macf. $x$ P. trifoliate) rootstocks at the Univ. of Florida's Citrus Research and Education Center in Lake Alfred were used in this study. The soil type of these sites is Candler fine sand with low water holding capacity and low organic matter. Each site was subdivided by rows or sections to form a random block design. Trees received normal grove management, irrigation, pest control, and fertilization. During the dry season between late October and May, irrigation by microsprinklers was applied at the rate of 170 to $227 \mathrm{~L} /$ tree twice per week as needed. Harvest dates were the normal harvest period for either variety in Florida. 'Hamlin' is harvested between November and February, whereas 'Valencia' is harvested between February and June. Bloom time for both varieties is normally in mid-March (Davies and Albrigo, 1994)

Trunk Shaker. A prototype (Dotan Ltd., Migdal Hae'mek, Israel) FMC linear-type trunk-shaking system (FMC Corp., Lakeland, Fla.) was used in this study. The padded clamp shaker head was equipped with $70.8 \mathrm{~kg}$ of unbalanced weight and connected by a power take off to a tractor engine operating at $2100 \mathrm{rpm}$. This weight and power combination was selected to generate a shaking frequency of $4 \mathrm{~Hz}$ with a maximum trunk displacement of $6.5 \mathrm{~cm}$. The shaking frequency and force output were evaluated on adjacent trees with a set of accelerometers (PCB 35B33; PCB Piezotronics, Depew, N.Y.) and high-speed portable data acquisition systems (WavePort/PE8; Iotech, Cleveland). Trunk displacement was measured directly using a measuring tape.

EXPERIMENT 1. Grove site one contained forty-five 14-yearold 'Hamlin'/'Swingle' trees in an east-west oriented row. Trees were $3.5 \mathrm{~m}$ tall and spaced at $6.1 \mathrm{~m}$ between rows and $4.6 \mathrm{~m}$ within rows. The trunk diameter averaged $14 \mathrm{~cm}$ at $30 \mathrm{~cm}$ above ground. Thirty uniform trees were grouped into five blocks of six trees. Irrigation was withheld for 3 weeks before harvest and no rainfall was recorded during this period. On 7 Jan. 2004, two trees in each block were harvested by hand $(\mathrm{Hd})$ and three trees were harvested by the trunk shaker. Hand harvesting removed 100\% of the fruit whereas mechanically harvesting removed $>90 \%$ of the fruit. Two trees harvested by the trunk shaker were subjected to $10 \mathrm{~s}$ shaking time (10S) and the other tree to $20 \mathrm{~s}(20 \mathrm{~S})$. The remaining tree in each block was not harvested and served as an un-harvested control (C). Irrigation was resumed in this grove the day after harvest except on one of the hand-harvested trees (HdD) and one of the $10 \mathrm{~s}$ mechanical harvested trees (10SD) in each block. To test effects of drought stress, irrigation was withheld from these trees for one additional month.

To characterize physiological responses of trees, mid-day stem water potential $\left(\Psi_{\text {stem }}\right)$, leaf gas exchange, and leaf chlorophyll fluorescence were measured $1 \mathrm{~d}$ before harvest and every 1 to 3 d thereafter until 6 Feb. 2004. Details of physiological measurements are described below.

EXPERIMENT 2. Grove site two contained thirty-eight 12-yearold 'Hamlin'/'Carrizo' trees in five north-south oriented rows. Trees were $3.7 \mathrm{~m}$ tall and spaced at 4.5 to $9 \mathrm{~m}$ between rows and $3 \mathrm{~m}$ within rows. The trunk diameter averaged $12.6 \mathrm{~cm}$ at 30 $\mathrm{cm}$ above ground. Twenty-five uniform trees were grouped by rows into five blocks of five trees. Irrigation was withheld from this grove site for 2 weeks before harvest on 28 Jan., but 33.78 $\mathrm{mm}$ rain fell on 18 and $19 \mathrm{Jan}$. and another $13.46 \mathrm{~mm}$ on $27 \mathrm{Jan}$. Consequently, soil was well watered prior to harvest. Two trees in each block were harvested by hand $(\mathrm{Hd})$ whereas three others were harvested using the trunk shaker as above. One mechanically harvested tree in each block was shaken for $10 \mathrm{~s}(10 \mathrm{~S})$ and the others for $30 \mathrm{~s}(30 \mathrm{~S})$ shaking time. After harvest, irrigation was resumed in this grove except on one of the hand harvested (HdD) and the 30S trees (30SD) in each block, in which irrigation was withheld for one additional week. Mid-day $\Psi_{\text {stem }}$ and leaf gas exchange was measured on 23 and 29 Jan. and 5 Feb. as described below.

EXPERIMENT 3. Grove site three contained forty 15-year-old 'Valencia'/'Swingle' trees in a north-south oriented row. Trees were $3.5 \mathrm{~m}$ tall and spaced at $4.56 \mathrm{~m}$ between rows and $2.13 \mathrm{~m}$ within rows. The trunk diameter averaged $36.8 \mathrm{~cm}$ at $30 \mathrm{~cm}$ above ground. Twenty-five uniform trees in full bloom were grouped into five blocks of five trees. Soil was well watered since irrigation at the rate of $227 \mathrm{~L} /$ tree was applied daily to this grove site from 11 to 15 Mar. plus $36.07 \mathrm{~mm}$ rain fell on $15 \mathrm{Mar}$. and $55.12 \mathrm{~mm}$ on 16 Mar. Two trees in each block were harvested by the trunk shaker for $10 \mathrm{~s}$ on 17 Mar. One tree was hand harvested on 19 Mar. and another by the trunk shaker for $20 \mathrm{~s}$. The remaining tree in each block was not harvested (C). After harvest, a portion of the bark was removed from the main trunk of one of the 10S trees in each block using a sharp knife to simulate severe bark injury (10SB) by the trunk clamp. An average of $7.5 \times 21.2$-cm bark area $\approx 20$ to $40 \mathrm{~cm}$ above the soil surface on both the north and south side of the main trunk was removed. This corresponded to the area that was in contact with the shaker clamp pads. The total width of the removed bark equaled $42 \%$ of the trunk circumference. After 19 Mar., irrigation was withheld from trees that had been harvested until late April, while a regular irrigation schedule was continued on the un-harvested control trees. Mid-day $\Psi_{\text {stem }}$ and leaf water potential $\left(\Psi_{\text {leaf }}\right)$ were measured as described below every one to three days between 18 Mar. and 4 Apr., and again on 20 and 28 Apr.

Soil water content was measured gravimetrically immediately after $\Psi$ measurements. Five soil samples from the root zone were collected at each measurement date at depths of 0 to $30 \mathrm{~cm}$ and 30 to $60 \mathrm{~cm}$. Soil water content was calculated by the difference between fresh and oven-dried soil weight.

LEAF AND STEM WATER POTENTIAL MEASUREMENTS. Mid-day $\Psi_{\text {stem }}$ and $\Psi_{\text {leaf }}$ were measured with a pressure chamber (Scholander et al., 1965) between 1330 and $1500 \mathrm{HR} ; \Psi_{\text {stem }}$ was measured on leaves that had been enclosed in plastic bags and covered by aluminum foil at least $3 \mathrm{~h}$ before measurement. Two exposed mature leaves from the last mature summer or spring flushes were used for each mid-day $\Psi_{\text {stem }}$ measurement. $\Psi_{\text {leaf }}$ was measured on uncovered, transpiring leaves immediately following $\Psi_{\text {stem }}$ measurements on two similar adjacent leaves.

LEAF GAS EXCHANGe MEASUREMENTS. Leaf gas exchange was measured with a portable photosynthesis system (LI-6200; LI- 
COR, Lincoln, Nebr.) on selected clear days between 0930 and 1130 HR. Photosynthetic photon flux density (PPFD) was greater than $900 \mu \mathrm{mol} \cdot \mathrm{m}^{-2} \cdot \mathrm{s}^{-1}$ during all measurements. Leaf temperature in the measurement cuvette was usually 2 to $3{ }^{\circ} \mathrm{C}$ above ambient air temperature. Relative humidity (RH) inside the cuvette was close to ambient RH. Measurements were made across all treatments in two 1-h blocks to allow testing for effects of changing environmental conditions over time. On each date measurements were taken on two to three healthy light-exposed mature leaves on the last summer or spring flushes on each tree. Net assimilation of $\mathrm{CO}_{2}\left(\mathrm{~A}_{\mathrm{CO} 2}\right)$, stomata conductance $\left(\mathrm{g}_{\mathrm{s}}\right)$, transpiration $(\mathrm{E})$, and leaf water use efficiency [WUE (micromoles $\mathrm{CO}_{2}$ per millimole $\left.\mathrm{H}_{2} \mathrm{O}\right)$ ] was calculated.

LEAF CHLOROPHYLl FLUORESCENCE MEASUREMENTS. Chlorophyll fluorescence was measured with a pulse-modulated fluorometer (OS-1-FL; Opti-Science, Tyngsboro, Mass.) on selected days between 1300 and $1330 \mathrm{HR}$. Two leaves from each tree were dark-adapted with leaf clips for at least $2 \mathrm{~h}$ prior to measurement to ensure the photosystem II reaction centers were in an active open status. The minimal fluorescence emission from the darkadapted leaf area $\left(F_{o}\right.$, nomenclature from van Kooten and Snel, $1990)$ was excited by low intensity $\left(<1 \mathrm{\mu mol} \cdot \mathrm{m}^{-2} \cdot \mathrm{s}^{-1}\right)$ modulated 655-nm light and was detected in the 700- to 750-nm ranges. After $F_{o}$ was recorded the photosystem was saturated by a high intensity $\left(\approx 15,000 \mu \mathrm{mol} \cdot \mathrm{m}^{-2} \cdot \mathrm{s}^{-1}\right), 350$ - to 690 -nm light pulse for $1 \mathrm{~s}$ to induce the maximal fluorescence from the dark-adapted leaf area $\left(F_{m}\right)$. Variable fluorescence from the dark-adapted leaf area $\left(F_{v}\right)$ was calculated from $\left(F_{m}-F_{o}\right)$ and maximum quantum efficiency of PSII photochemistry was derived from $F_{v} / F_{m}$ (van Kooten and Snel, 1990). Measurements were taken on every tree in Expts. 1 and 2.

ENVIRONMENTAL DATA AND STATisTiCAL ANALYSis. Daily temperature, precipitation, and $\mathrm{RH}$ for the Lake Alfred site were obtained from Florida Automated Weather Network (Univ. of Florida/Institute of Food and Agricultural Sciences, 2005). Maximum daily vapor pressure deficit (VPD) was derived from maximum day temperature and minimum RH.

Data were subjected to analysis of variance (ANOVA). Each tree was an experiment unit. Measurements from each tree were averaged before analysis using general linear model or balanced model procedures. Data collected after harvest were also pooled and subjected to repeated measures ANOVA where appropriate. Mean values of treatments with or without standard error are presented. Significant differences were determined at $P \leq 0.05$, 0.01 , or 0.001 and separated by Dunn's or Duncan's multiple comparison tests where appropriate. Due to lack of interaction between treatment and blocks overtime, only treatment and block effects are reported.

\section{Results}

\section{Tree water status}

Experiment 1. A moderate drought stress occurred as the average mid-day $\Psi_{\text {stem }}$ was below $-1.5 \mathrm{MPa} 5 \mathrm{~d}$ before harvest on 7 Jan. (data not shown). Mid-day $\Psi_{\text {stem }}$ of trees re-watered on 8 Jan., $1 \mathrm{~d}$ after harvest, recovered immediately. Although $\mathrm{C}$ and Hd trees had slightly higher $\Psi_{\text {stem }}(-1.23 \mathrm{MPa})$ than that of $10 \mathrm{~S}$ and $20 \mathrm{~S}$ trees $(-1.33 \mathrm{MPa})$, this difference was not significant. Mid-day $\Psi_{\text {stem }}$ of trees un-irrigated after harvest (HdD and 10SD) remained below $-1.41 \mathrm{MPa}$. A similar trend occurred the next day except for $20 \mathrm{~S}$ trees, in which the mid-day $\Psi_{\text {stem }}$ declined to the level of the continuously drought-stressed trees and that was

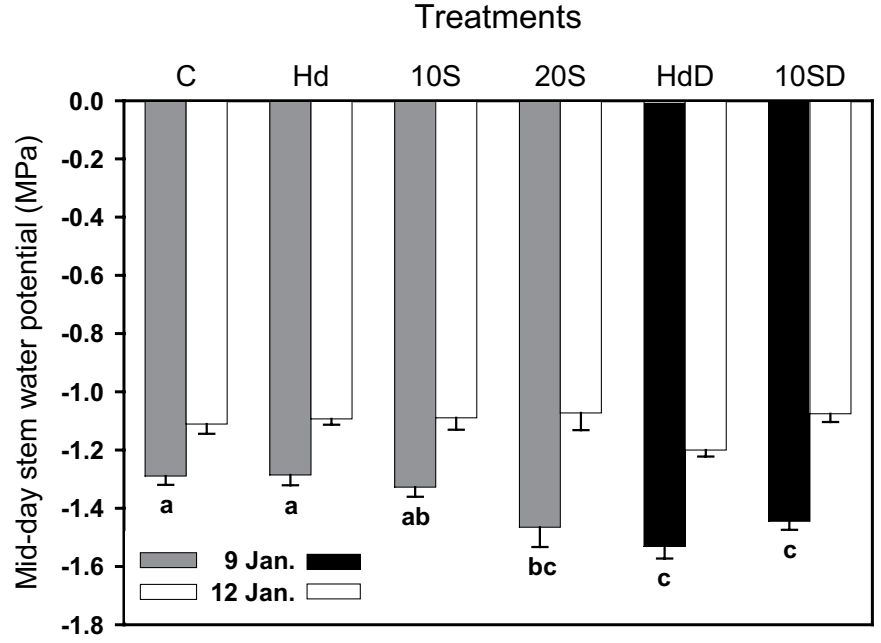

Fig. 1. Effect of mechanical harvesting and irrigation on mid-day (1330 to 1500 HR) stem water potential in 'Hamlin' citrus trees (Expt. 1); $\mathrm{C}=$ trees were not harvested, $\mathrm{Hd}=$ hand harvest, $10 \mathrm{~S}=10 \mathrm{~s}$ trunk shaking, $20 \mathrm{~S}=20 \mathrm{~s}$ trunk shaking, $\mathrm{HdD}=$ hand harvest and postharvest drought stress, 10SD = $10 \mathrm{~s}$ trunk shaking and postharvest drought stress. Trees were harvested on 7 Jan. 2004. Trees did not received water 3 weeks prior to harvest. Trees other than postharvest drought treatments received irrigation on $8 \mathrm{Jan}$; $8.6 \mathrm{~mm}$ rainfall was recorded after 9 Jan. measurements. Date represents mean values of 10 replicated leaves. Vertical bars represent standard errors. Mean separation by Duncan's multiple comparison $(P \leq 0.05)$.

significantly lower than that of $\mathrm{C}$ and Hd trees on 9 Jan. (Fig. 1). The 8.6-mm precipitation in the evening of 9 Jan. diminished any difference in $\Psi_{\text {stem }}$ among treatments by 11 Jan. and thereafter. The regular irrigation and a total amount of $53.1 \mathrm{~mm}$ precipitation maintained all mid-day $\Psi_{\text {stem }}$ above $-1.2 \mathrm{MPa}$ until 6 Feb.

ExPT. 2. The rainfall before and after harvest also ensured a high water status with mid-day $\Psi_{\text {stem }}$ at $-1.16 \mathrm{MPa}$ in all trees regardless of the harvest and irrigation treatments (data not shown). However, on $5 \mathrm{Feb}$, a dry hot day when the temperature exceeded $29^{\circ} \mathrm{C}$, trees harvested by hand with or without postharvest irrigation, had lower mid-day $\Psi_{\text {stem }}(-1.41 \mathrm{Mpa})$ than trees harvested with the trunk shaker $(-1.3 \mathrm{MPa}, P=0.003)$.

ExPT.3. The $5 \mathrm{~d}$ of preharvest irrigation plus $36 \mathrm{~mm}$ precipitation prior to harvest on 17 Mar., resulted in a high $\Psi_{\text {stem }}$ of -0.79 in all trees (Fig. 2A) and high soil water content (Fig. 2B). Since there was no rainfall until 3 weeks after harvest, the mid-day $\Psi_{\text {stem }}$ and soil water content gradually declined. The initially high soil water content, however, apparently resulted in no drought symptoms on trees regardless of irrigation, harvest treatments, or bark removal. The only exception was on 29 Mar. after several clear days with high maximum temperature and VPD (Fig. 2C). On this day, trees without irrigation, regardless of harvest methods and bark removal, had lower mid-day $\Psi_{\text {stem }}$ than $\mathrm{C}$ trees that had been irrigated regularly $(P=0.017)$. Irrigation was resumed on all trees on 3 Apr. and $\Psi_{\text {stem }}$ began to increase 2 d later. There was no significant difference in $\Psi_{\text {stem }}$ among treatments through late April.

Similar results in mid-day $\Psi_{\text {leaf }}$ were obtained as values were generally 0.1 to $0.3 \mathrm{MPa}$ lower than $\Psi_{\text {stem }}$ measured at the same time of day (data not shown). Sample variations, however, resulted in no difference in $\Psi_{\text {leaf }}$ among treatments.

Leaf Gas EXChange. Overall, there was no significant difference in $\mathrm{A}_{\mathrm{CO} 2}, \mathrm{~g}_{\mathrm{s}}, \mathrm{E}$, and WUE between hand and mechanical harvested trees in Expt. 1 before and after harvest (Table 1). Mean gas exchange values on 6 Jan. were relatively high during the 


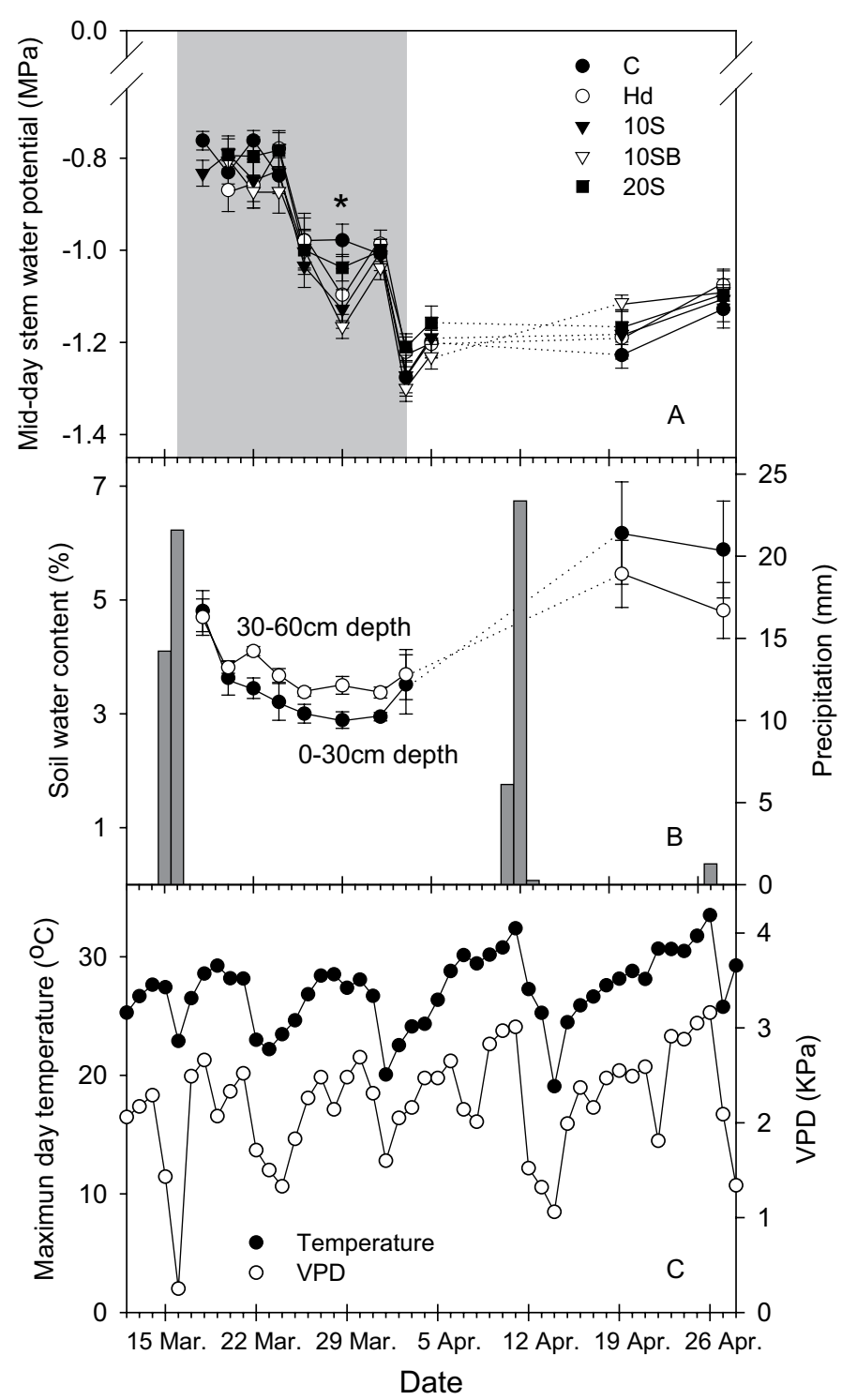

Fig. 2. (A) Effect of mechanical harvesting and irrigation on mid-day stem water potential in 'Valencia' citrus trees in full bloom (Expt. 3); $\mathrm{C}=$ Trees were not harvested, $\mathrm{Hd}=$ hand harvest, $10 \mathrm{~S}=10 \mathrm{~s}$ trunk shaking, $10 \mathrm{SB}=10 \mathrm{~s}$ trunk shaking and partial bark removal, $20 \mathrm{~S}=20$ s trunk shaking. Trees were harvested on 17 or 19 Mar. 2004. Irrigation was withheld from all trees except $\mathrm{C}$ trees between 16 Mar. and 3 Apr. (shaded area). The asterisk indicates statistical significance $(P=0.017)$. (B) Soil water content (lines) and precipitation (bars), and $(\mathbf{C})$ maximum day temperature (T) and vapor pressure deficit (VPD) during experiment dates. Vertical bars represent standard errors.

winter in spite of the moderate drought stress imposed before trees were harvested on 7 Jan. After harvest, gas exchange readings in all trees were significant lower on 8 Jan and thereafter. Trees that were mechanically harvested and that were continuously not irrigated had lower $\mathrm{A}_{\mathrm{CO} 2}, \mathrm{~g}_{\mathrm{s}}$, and $\mathrm{E}$ than $\mathrm{C}$ and $\mathrm{Hd}$ trees. The unharvested $\mathrm{C}$ trees had consistently higher $\mathrm{A}_{\mathrm{CO} 2}$ than all harvested trees as shown by the postharvest means across 8 to 22 Jan. The differences, however, were not significant within individual measurement dates. Gas exchange rates remained relatively low after the harvest date until 22 Jan. There was little treatment effect on WUE, although after harvest, $\mathrm{C}$ trees with fruit had higher WUE than harvested trees, especially the 20S and HdD trees. Due to the greater reductions in $\mathrm{E}$ than in $\mathrm{A}_{\mathrm{CO} 2}$, WUE after harvest was higher than before harvest in all trees.
Table 1. The effect of harvesting and irrigation on leaf gas exchange in 'Hamlin' citrus trees (Expt. 1). Trees were harvested on 7 Jan. 2004.

\begin{tabular}{|c|c|c|c|c|c|c|}
\hline \multirow[b]{2}{*}{ Treatments $^{\mathrm{z}}$} & \multicolumn{5}{|c|}{ Date of measurements } & \multirow{2}{*}{$\begin{array}{c}\text { Mean after } \\
\text { harvest }\end{array}$} \\
\hline & 6 Jan. & 8 Jan. & 12 Jan. & 15 Jan. & 22 Jan. & \\
\hline & \multicolumn{6}{|c|}{ Assimilation of $\mathrm{CO}_{2}\left(\mu \mathrm{mol} \cdot \mathrm{m}^{-2} \cdot \mathrm{s}^{-1}\right)$} \\
\hline $\mathrm{C}$ & 10.7 & 5.4 & 4.9 & 8.7 & 5.0 & $6 a$ \\
\hline $\mathrm{Hd}$ & 11.7 & 5.4 & 3.1 & 7.4 & 4.2 & $5.01 \mathrm{ab}$ \\
\hline $10 \mathrm{~S}$ & 9.2 & 3.9 & 3.0 & 8.9 & 4.1 & $4.98 \mathrm{ab}$ \\
\hline $20 \mathrm{~S}$ & 8.2 & 3.7 & 2.5 & 5.0 & 3.2 & $3.6 \mathrm{~b}$ \\
\hline $\mathrm{HdD}$ & 9.8 & 3.5 & 2.9 & 6.6 & 2.8 & $3.95 \mathrm{~b}$ \\
\hline 10SD & 10.4 & 3.7 & 3.1 & 6.1 & 4.5 & $4.3 \mathrm{~b}$ \\
\hline \multicolumn{7}{|l|}{ Significance } \\
\hline Treatment & NS & NS & NS & NS & NS & $* *$ \\
\hline \multirow[t]{2}{*}{ Block } & $*$ & NS & $*$ & NS & NS & $*$ \\
\hline & \multicolumn{6}{|c|}{ Stomatal conductance $\left(\mathrm{mol} \cdot \mathrm{m}^{-2} \cdot \mathrm{s}^{-1}\right)$} \\
\hline $\mathrm{C}$ & 0.306 & 0.054 & 0.063 & 0.121 & 0.069 & 0.077 \\
\hline Hd & 0.3 & 0.062 & 0.047 & 0.106 & 0.062 & 0.069 \\
\hline $10 \mathrm{~S}$ & 0.214 & 0.053 & 0.048 & 0.144 & 0.062 & 0.077 \\
\hline $20 \mathrm{~S}$ & 0.267 & 0.047 & 0.041 & 0.092 & 0.06 & 0.06 \\
\hline $\mathrm{HdD}$ & 0.209 & 0.037 & 0.037 & 0.097 & 0.052 & 0.056 \\
\hline $10 S D$ & 0.267 & 0.034 & 0.051 & 0.097 & 0.064 & 0.062 \\
\hline \multicolumn{7}{|l|}{ Significance } \\
\hline Treatment & NS & NS & NS & NS & NS & NS \\
\hline \multirow[t]{2}{*}{ Block } & NS & NS & NS & NS & NS & NS \\
\hline & \multicolumn{6}{|c|}{ Transpiration $\left(\mathrm{mmol} \cdot \mathrm{m}^{-2} \cdot \mathrm{s}^{-1}\right)$} \\
\hline $\mathrm{C}$ & 7.82 & $1.62 \mathrm{ab}$ & 1.25 & 2.13 & 1.31 & 1.58 \\
\hline Hd & 8.77 & $1.9 \mathrm{a}$ & 0.95 & 1.9 & 1.3 & 1.51 \\
\hline $10 \mathrm{~S}$ & 8.23 & $1.25 \mathrm{~b}$ & 1.03 & 2.2 & 1.29 & 1.44 \\
\hline $20 \mathrm{~S}$ & 7.61 & $1.27 \mathrm{~b}$ & 1 & 1.6 & 1.28 & 1.29 \\
\hline $\mathrm{HdD}$ & 7.74 & $1.38 \mathrm{ab}$ & 1.05 & 1.87 & 1.31 & 1.40 \\
\hline 10SD & 8.32 & $1.45 \mathrm{ab}$ & 1.27 & 1.75 & 1.41 & 1.47 \\
\hline \multicolumn{7}{|l|}{ Significance } \\
\hline Treatment & NS & $*$ & NS & NS & NS & NS \\
\hline \multirow[t]{2}{*}{ Block } & NS & NS & NS & NS & NS & $*$ \\
\hline & \multicolumn{6}{|c|}{ Water use efficiency ( $\mu$ mol $\mathrm{CO}_{2}$ per mmol $\left.\mathrm{H}_{2} \mathrm{O}\right)$} \\
\hline $\mathrm{C}$ & 1.34 & 3.2 & $3.59 \mathrm{a}$ & 3.97 & 3.7 & $3.71 \mathrm{a}$ \\
\hline Hd & 1.34 & 2.8 & $3.03 \mathrm{ab}$ & 3.68 & 3.03 & $3.14 \mathrm{ab}$ \\
\hline $10 \mathrm{~S}$ & 1.1 & 2.97 & $2.73 \mathrm{~b}$ & 4 & 3.02 & $3.18 \mathrm{ab}$ \\
\hline $20 \mathrm{~S}$ & 1.09 & 2.68 & $2.37 \mathrm{~b}$ & 2.94 & 2.28 & $2.57 \mathrm{~b}$ \\
\hline $\mathrm{HdD}$ & 1.24 & 2.5 & $2.66 \mathrm{~b}$ & 3.46 & 1.94 & $2.66 \mathrm{~b}$ \\
\hline 10SD & 1.29 & 2.41 & $2.47 \mathrm{~b}$ & 3.28 & 3.13 & $2.82 \mathrm{~b}$ \\
\hline Significance & & & & & & \\
\hline Treatment & NS & NS & $* *$ & NS & NS & $* *$ \\
\hline Block & $*$ & NS & $* * *$ & NS & NS & $*$ \\
\hline
\end{tabular}

${ }_{\mathrm{z}} \mathrm{C}=$ trees were not harvested, $\mathrm{Hd}=$ hand harvest, $10 \mathrm{~S}=10$ s trunk shaking, $20 \mathrm{~S}=20 \mathrm{~s}$ trunk shaking, $\mathrm{HdD}=$ hand harvest and postharvest drought stress, $10 \mathrm{SD}=10 \mathrm{~s}$ trunk shaking and postharvest drought stress.

Ns, $, * * *, * * *$ Nonsignificant or significant difference at $P \leq 0.05,0.01,0.001$, respectively. Letters within rows indicate treatment mean separation by Duncan's multiple comparison test at $P \leq 0.05$.

There were few significant differences in gas exchange among treatments in Expt. 2. Mean $\mathrm{A}_{\mathrm{CO} 2}$ before harvest was 5.8 to $7.5 \mu \mathrm{mol} \cdot \mathrm{m}^{-2} \cdot \mathrm{s}^{-1}, \mathrm{~g}_{\mathrm{s}}$ was 0.07 to $0.08 \mathrm{~mol} \cdot \mathrm{m}^{-2} \cdot \mathrm{s}^{-1}$, and $\mathrm{E}$ was 1.5 to $2.5 \mathrm{mmol} \cdot \mathrm{m}^{-2} \cdot \mathrm{s}^{-1}$. Mean $\mathrm{A}_{\mathrm{CO} 2}$ after harvest was 4.5 to 5.5 $\mu \mathrm{mol} \cdot \mathrm{m}^{-2} \cdot \mathrm{s}^{-1}, \mathrm{~g}_{\mathrm{s}}$ was 0.05 to $0.08 \mathrm{~mol} \cdot \mathrm{m}^{-2} \cdot \mathrm{s}^{-1}$, and $\mathrm{E}$ was 1.3 to $1.8 \mathrm{mmol} \cdot \mathrm{m}^{-2} \cdot \mathrm{s}^{-1}$.

LEAF CHLOROPHYLl FLuORESCENCE. Similar to leaf gas exchange, there was no significant treatment effects on photosystem II efficiency as indicated by chlorophyll fluorescence $F_{v} / F_{m}$ of leaves from all trees (Table 2). Uniformly high values of $F_{v} / F_{m}$ 
Table 2. The effect of harvesting and irrigation on leaf photosystem II efficiency as indicated by leaf chlorophyll fluorescence $\left(F_{v} / F_{m}\right)$ in 'Hamlin' citrus tree (Expt. 1). Trees were harvested on 7 Jan. 2004.

\begin{tabular}{lccccccc}
\hline & \multicolumn{6}{c}{ Photosystem II efficiency $\left(F_{v} / F_{m}\right)$} & \multirow{2}{*}{$\begin{array}{c}\text { Mean after } \\
\text { Treatments }\end{array}$} \\
\cline { 2 - 7 } & 5 Jan. & 8 Jan. & 9 Jan. & 12 Jan. & 15 Jan. & 22 Jan. & harvest \\
\hline C & 0.81 & 0.78 & 0.80 & $0.78 \mathrm{ab}$ & 0.77 & $0.78 \mathrm{a}$ & 0.78 \\
Hd & 0.80 & 0.76 & 0.81 & $0.79 \mathrm{ab}$ & 0.76 & $0.73 \mathrm{ab}$ & 0.77 \\
10S & 0.80 & 0.77 & 0.79 & $0.79 \mathrm{a}$ & 0.77 & $0.73 \mathrm{ab}$ & 0.77 \\
20S & 0.81 & 0.79 & 0.80 & $0.73 \mathrm{ab}$ & 0.75 & $0.72 \mathrm{~b}$ & 0.76 \\
HdD & 0.80 & 0.77 & 0.79 & $0.74 \mathrm{ab}$ & 0.71 & $0.75 \mathrm{ab}$ & 0.75 \\
10SD & 0.81 & 0.73 & 0.78 & $0.72 \mathrm{~b}$ & 0.75 & $0.74 \mathrm{ab}$ & 0.74 \\
Significance & NS & NS & NS & $*$ & NS & $*$ & NS
\end{tabular}

${ }^{2} \mathrm{C}=$ trees were not harvested, $\mathrm{Hd}=$ hand harvest, $10 \mathrm{~S}=10 \mathrm{~s}$ trunk shaking, $20 \mathrm{~S}=20 \mathrm{~s}$ trunk shaking, $\mathrm{HdD}=$ hand harvest and postharvest drought stress, $10 \mathrm{SD}=10 \mathrm{~s}$ trunk shaking and postharvest drought stress.

Ns, *Nonsignificant or significant difference at $P \leq 0.05$, respectively. Letters within rows indicate treatment mean separation by Duncan's multiple comparison test at $P \leq 0.05$.

(0.8 to 0.81$)$ were recorded before harvest. The $F_{v} / F_{m}$ readings decreased on 8 Jan. and thereafter. After harvest, $\mathrm{C}$ trees had a slightly higher $F_{v} / F_{m}$ than the others, and continuously drought stressed-trees (HdD and 10SD) had lower $F_{v} / F_{m}$.

\section{Discussion}

Using the commercial range of shaking time of about $10 \mathrm{~s}$, trees harvested by the trunk shaker maintained water status and gas exchange rates similar to trees harvested by hand under most conditions during the harvest season. Even after an excessive shaking time of $\geq 20 \mathrm{~s}$ that was expected to cause damage to roots and trunk bark of actively growing trees, mechanically harvested trees did not develop water stress symptoms when the grove was well watered (Expts. 2 and 3). When soil was semidry, however, there was a rapid reduction in $\Psi_{\text {stem }}$ of mechanical harvested trees, especially of $20 \mathrm{~S}$ trees that developed stress similar to that of nonirrigated trees (Fig. 1). Similar to drought stress from root damage that occurs when transplanting mature trees (Castle, 1993) and, root pruning studies (Moreshet et al., 1988), the shaker-induced drought stress was ephemeral and disappeared once the grove was fully watered. The common practice of ceasing irrigation before and after mechanical harvesting to facilitate machine access might not be advisable if the grove has experienced any drought stress.

An average of $12 \%$ of total leaf area was removed by the trunk shaker in this study compared to $<2 \%$ by hand harvest $(\mathrm{Li}$ and Syvertsen, 2004a, 2004b). Since canopy E is proportional to canopy leaf area (Atkinson, 1978; Li et al., 2003), this amount of leaf loss should have decreased canopy E. It is not surprising, therefore, trees harvested by the trunk shaker had temporarily higher mid-day $\Psi_{\text {stem }}$ than trees harvested by hand in dry, hot days when water uptake from the soil was not limited such as on 5 Feb. in Expt. 2.

Chronic water stress induced by xylem embolism and reduced trunk hydraulic conductance after severe wind and shaking damage by large typhoons, resulted in decline and dieback of tall hinoki cypress trees [Chamaecyparis obtuse (Siebold \& Zucc.) Endl.] several years after the damage (Ueda and Shibata, 2004). It is not clear whether the short-term trunk shaking that occurred during mechanical harvesting would cause similar results. However, the rapid recovery of stem water potential in $20 \mathrm{~S}$ trees and the insignificant differences in water status between hand and mechanical harvested trees indicated that any physical injuries caused by the trunk shaker did not affect the overall water relations. Thus, canopy transpiration, xylem transport, and root uptake of water apparently were unaffected.

Leaf gas exchange was not affected by defoliation or putative root injuries caused by the trunk shaker. Although photosynthesis gradually decreases when citrus trees suffer drought (Mataa et al., 1998), the mild drought stress and the rainfall after harvest in Expt. 1, resulted in water potentials that were apparently not low enough to reduce gas exchange. Partial defoliation has been reported to increase leaf photosynthetic ability in remaining leaves of citrus seedlings, which supports the increased carbohydrate demand for regrowth (Syvertsen, 1994). Manually removing up to $25 \%$ canopy leaf area in mature citrus trees, however, did not induce photosynthetic compensation in remaining lightexposed leaves (Garcia-Sanchez, unpublished). Similarly, the mild defoliation caused by mechanical harvesting in this study, appeared incapable of inducing any photosynthetic compensation mechanism in light-exposed leaves. In addition, citrus trees have a very high canopy density with leaf area indexes approaching 11 (Jahn, 1979). The severity of leaf loss in trees after mechanical harvesting was not expected to remarkably reduce total canopy light interception. Since citrus leaves are capable of acclimating to a wide range of changing light environments even after fully mature (Syvertsen and Smith, 1984), preshaded leaves in the canopy might have partially restored their gas exchange ability in response to the increasing light exposure after mechanical harvesting. Therefore, the small reduction in leaf area after mechanical harvesting might be expected to have little effect on whole-canopy photosynthesis.

The low leaf gas exchange after harvest in Expt. 1, appeared to be directly related to the low temperature (Guo et al., 2003; Syvertsen and Lloyd, 1994). Before harvest, the day/night temperature had averaged at $27 / 12^{\circ} \mathrm{C}$ for 1 week and moderate gas exchange readings were recorded on $6 \mathrm{Jan}$. The day/night temperature decreased to $15 / 5^{\circ} \mathrm{C} 1 \mathrm{~d}$ after harvest and to $17.5 / 2.5^{\circ} \mathrm{C}$ on 10 and 11 Jan. Until the end of January the temperature remained relative low as did the leaf gas exchange rate. The variations in gas exchange data can be attributed to the variations due to leaf age and to block effects, which reflects the time-related changes in temperature and VPD during measurements especially during the cool winter days.

Although chlorophyll fluorescence has been used to investigate plant photosynthetic responses to various types of environmental stresses, the feasibility of fluorescence indexes depends on the type and the magnitude of the stress (van Kooten and Snel, 1990). In general, chlorophyll fluorescence was not sensitive to mild or moderate drought stress, as $F_{v} / F_{m}$ was not affected in many crops with imposed drought stress (Baker and Rosenqvist, 2004). Salinity induced drought stress also did not affect chlorophyll fluorescence emission in citrus (Lloyd et al., 1987). $F_{v} / F_{m}$ decreased only after long-term drought stress in apple (Malus $\times$ domestica Borkh.) leaves (Massacci and Jones, 1990). In contrast, $F_{v} / F_{m}$ is a powerful probe for detecting photoinhibition caused by chilling temperature in citrus (Guo et al., 2003) and other tropical fruit trees (Nir et al., 1997). Similar to gas exchange measurements, we measured low $F_{v} / F_{m}$ readings after harvest in all trees regardless of treatments, suggesting that the reduction in photosystem II efficiency after harvest was the result of cool temperature.

Crop load can increase photosynthesis and chlorophyll fluorescence in citrus (Syvertsen et al., 2003), apple (Tartachnyk and Blanke, 2004; Wünsche et al., 2000), and many other fruit trees 
(Urban, et al., 2003). In Expt. 1 the un-harvested control trees had consistently higher gas exchange and photosystem efficiency but this crop load effect was not significant. It is possible that the low temperature after harvest obscured significant crop load effects on $\mathrm{A}_{\mathrm{CO} 2}$. On the other hand, any low-temperature effect in Expt. 2 was eliminated because the weather remained warm before and after harvest. The slightly lower gas exchange in all treatments after harvest might therefore, be attributable to the loss of a crop effect.

\section{Conclusions}

Healthy, well-managed citrus trees were capable of tolerating the defoliation as well as any potential root and bark injury caused by the mechanical harvesting trunk shaker. Mechanical harvested trees did not develop any physiological stress as measured by stem water potential, leaf gas exchange, and photosystem efficiency. Trees that were shaken for an excessive duration might have had more severe root damage and thus developed temporary drought stress when soil moisture was relatively low. This drought stress can be avoided by limiting shaking time to $<10 \mathrm{~s}$ and with proper grove irrigation. However, any impact of mechanical harvesting on whole-canopy light interception and gas exchange has yet to be determined. Potential effects of repeated mechanical harvesting on tree vigor, direct root injury by trunk shaking, and the growth of fine roots in relation to potential phloem injury warrant investigation.

\section{Literature Cited}

Abdel-Fattah, H.M., K.A. Shackel, and D.C. Slaughter. 2003. Substantial vertical tree displacements occur during almond shaker harvesting. Appl. Eng. Agr. 19:145-150.

Affeldt, H.A., Jr., G.K. Brown, and J.B. Gerrish. 1989. A new shaker for fruit and nut trees. J. Agr. Eng. Res. 44:53-66.

Atkinson, D. 1978. Use of soil resources in high density planting systems, Acta Hort. 65:79-89.

Baker, N.R. and E. Rosenqvist. 2004. Applications of chlorophyll fluorescence can improve crop production strategies: An examination of future possibilities. J. Expt. Bot. 55:1607-1621.

Brown, G.K. 2005. New mechanical harvesters for the Florida citrus juice industry. HortTechnology 15:69-72.

Burton, C.L., N.L. Schulte-Pason, G.K. Brown, and D.E. Marshall. 1986. Influence of mechanical harvesting on cherry tree decline-Progress report. Amer. Soc.Agr. Eng. Paper No. 86-1559. Castle, W.S. 1983. Antitranspirant and root and canopy pruning effects on mechanically transplanted eightyear-old 'Murcott' citrus trees. J. Amer. Soc. Hort. Sci. 108:981-985.

Davies, F.S. and L.G. Albrigo. 1994. Citrus. CAB, Wallingford, U.K.

De Vay, J.E., F.L. Lukzic, H.English, E.E. Trujillo, and W.J. Moller. 1968. Ceratocystis canker of deciduous fruit trees. Phytopathology 58:949-954.

Fridley, R.B. 1983. Vibration and vibratory mechanisms for the harvest of tree fruits, p. 157-188. In: M. O'Brien, B.F. Cargill, and R.B. Fridley (eds.). Principles and practices for harvesting and handling fruits and nuts. AVI, Westport, Conn.

Glenn, D.M., D.L. Peterson, and S.S. Miller. 1995. Mechanical harvesting of peaches-Limited potential. HortScience 30:985-987.

Guo, Y., J. Su., H. Wang, Y. Shen, and L.Z. 2003. Attenuation of chilling effect on photosynthesis of satsuma mandarin (Citrus unshiu Marc.) by $\mathrm{NaHSO}_{3}$ application. Acta Hort. Sinica 30:195-197.

Gurusinghe, S.H. and K.A. Shackel. 1995. The relation of cambial zone mechanical strength to growth and irrigation of almond [Prunus dulcis (Mill.) Webb.] trees. J. Amer. Soc. Hort. Sci. 120:170-176.

Halderson, J.L. 1966. Fundamental factors in mechanical cherry harvesting. Trans. Amer. Soc. Agr. Eng. 9:681-684.

Hedden, S.L., D.B. Churchill, and J.D. Whitney. 1988. Trunk shakers for citrus harvesting-Part II: Tree growth, fruit yield and removal. Appl. Eng. Agr. 4:102-106.

Hedden, S.L., G.E. Coppock, and J.D. Whitney. 1983. Citrus harvest mechanization in Florida-Current situation. Trans. Amer. Soc. Agr. Eng. 26:397-398.

Jahn, O.L. 1979. Penetration of photosynthetically active radiation as a measurement of canopy density of citrus trees. J. Amer. Soc. Hort. Sci. 104:557-560.

Li, K.-T., A.N. Lakso, R. Piccioni, and T. Robinson. 2003. Summer pruning reduces whole-canopy carbon fixation and transpiration in apple trees. J. Hort. Sci. Biotech. 78:749-754.

Li, K.-T. and J. Syvertsen. 2004a. Does mechanical harvesting hurt your trees? Citrus Ind. 85(8):30-33.

Li, K.-T. and J.P. Syvertsen. 2004b. Physiological effects of mechanical harvesting in citrus trees. HortScience 39:885. (Abstr.)

Lloyd, J., J.P. Syvertsen, and P.E. Kriedemann. 1987. Salinity effects on leaf water relations and gas exchange of 'Valencia' orange, Citrus sinensis (L.) Osbeck, on rootstocks with different salt exclusion characteristics. Aust. J. Plant Physiol. 14:605-617.

Massacci, A. and H.G. Jones. 1990. Use of simultaneous analysis of gasexchange and chlorophyll fluorescence quenching for analyzing the effects of water stress on photosynthesis in apple leaves. Trees 4:1-8.

Mataa, M., S. Tominaga, and I. Kozaki. 1998. Relative effects of growth retardant (paclobutrazol) and water stress on tree growth and photosynthesis in ponkan (Citrus reticulate Blanco). J. Jpn. Soc. Hort. Sci. 67:28-34.

Moreshet, S., Y.Cohen, and M. Fuchs. 1988. Water use and yield of a mature shammouti orange orchard submitted to root volume restriction and intensive canopy pruning, p. 739-746. In: R. Goren and K. Mendel (Eds.). Proc. XI Intl. Citrus Congr. Balaban, Rehovot, Israel.

Nir, G., K. Ratner, E.E. Gussakovsky, and Y. Shahak. 1997. Photoinhibition of photosynthesis in mango leaves: Effect of chilly night. Acta Hort. 455:228-235.

O’Brien, M., B.F. Cargill, and R.B. Fridley. 1983. Principles and practices for harvesting and handling fruits and nuts. AVI, Westport, Conn.

Peterson, D.L. 1998. Mechanical harvest for process oranges. Appl. Eng. Agr. 14:455-458.

Scholander, P.F., H.T. Hammel, E.D. Bradstreet, and E.A. Hemmingsen. 1965. Sap pressure in vascular plants. Science 148:339-346.

Syvertsen, J.P. 1994. Partial shoot removal increases net $\mathrm{CO}_{2}$ assimilation and alters water relations of Citrus seedlings. Tree Physiol. 14:497-508.

Syvertsen, J.P., C. Goni, and A. Otero. 2003. Fruit load and canopy shading affect leaf characteristics and net gas exchange of 'Spring' navel orange trees. Tree Physiol. 23:899-906.

Syvertsen, J.P. and J.J. Lloyd. 1994. Citrus, p. 65-99. In: B. Schaffer and P.C. Andersen (eds.). Handbook of environmental physiology of fruit crops, Volume II: Sub-tropical and tropical crops. CRC Press, Boca Raton, Fla. Syvertsen, J.P. and M.L. Smith, Jr. 1984. Light acclimation in citrus leaves. I. Changes in physical characteristics, chlorophyll, and nitrogen content. J. Amer. Soc. Hort. Sci. 109:807-812.

Tartachnyk, I.I. and M.M. Blanke. 2004. Effect of delayed fruit harvest on photosynthesis, transpiration and nutrient remobilization of apple leaves. New Phytol. 164:441-450.

Ueda, M. and E. Shibata. 2004. Why do trees decline or dieback after a strong wind? Water status of hinoki cypress standing after a typhoon. Tree Physiol. 24:701-706.

University of Florida/Institute of Food and Agricultural Sciences. 2005. Florida automated weather network. 15 Jan. 2005. http://fawn.ifas.ufl.edu.

Urban, L., X. Le Roux, H. Sinoquet, S. Jaffuel, and M. Jannoyer. 2003. A biochemical model of photosynthesis for mango leaves: Evidence for the effect of fruit on photosynthetic capacity of nearby leaves. Tree Physiol. 23:289-300.

van Kooten, O. and F. Snel. 1990. The use of chlorophyll fluorescence nomenclature in plant stress physiology. Photosyn. Res. 25:147-150.

Whitney, J.D. 1995. A review of citrus harvesting in Florida. Trans. Citrus Eng. Conf. 41:33-60.

Wünsche, J.N., J.W. Palmer, and D.H. Greer. 2000. Effect of crop load on fruiting and gas-exchange characteristics of 'Braeburn'/M.26 apple trees at full canopy. J. Amer. Soc. Hort. Sci. 125:93-99. 